\title{
CULTURE AND CIVILIZATION OF WEST FROM THE PERSPECTIVE OF KASRAVI
}

\author{
Mohammad Mehdi Roshanfekr \\ Assistant Professor of University of Yasouj \\ M.m.r1345@mail.yu.ac.ir
}

\begin{abstract}
The time of Ahmad Kasravi which is from the beginning of the Constitutional Movement to start the second Pahlavi regime is the peak of the " Europe tendency movement" in Iran and in general in East. In other words, tendency to West in many aspects of life was common among people especially in those who had connection with Europe in different forms or had slight acquaintance. In such situation where many people and even so-called "intellectual" and "elite" level were speaking proudly about the culture and civilization of Europe and complying with Europeans was considered as an honor and privilege, Kasravi was a critic of culture and civilization of West despite having compatibility and cooperation with the government and wholeheartedly opposed the " Europe tendency movement" and defended what was intellectual and cultural richness of Iranians. The reality is that Kasravi has mostly seen the "ugliness" of West in most of his books and papers or a type of nationalism which is a combination of him being Iranian and from East and of course he has paid attention to both West and East based on theoretical foundations and principles that he adhered to and has scrutinized and sophisticated positive and negative aspects of each of them which is unique in its kind. He has warned everyone at the time when many people were not paying attention to the West's cultural invasion and he has understood the root of their main problems and has given solution by detailed and comprehensive study of Western life and has warned his countrymen about the good and mostly the bad of culture and civilization of West and has spoken about what the Iranians should not obtain and follow from West. This is a "descriptive analytical" article which has been carried out by referring to the original sources and the method of peacockery collection and then analysis and organization and deduction from it.
\end{abstract}

Keywords: Kasravi, Europeans, culture, civilization, West

\section{INTRODUCTION}

Culture and civilization of West is rooted in development of the Renaissance in all political, social, economic, cultural and industry aspects by relying on new science. Different ideational aspects of this transformation have been: Humanism, secularism, liberalism, rationality and materialism which modern state has had colonial results alongside it in its hardware aspect. The process of economic expansion led Western powers to form the first steps in in the economic aspect in addition to the issue of "free trade" in recent centuries and then try to digest the native cultures of other lands including East which has often been accompanied by acts of political and military domination. The important note is that some "theorist" have also been used by intellectuals patron of the same colonial Culture and civilization to pave the way in order to fulfill this matter and sell it to local residents.

Iran's geographical location and its economic resources also made this country to be the place and subject of dispute of colonial powers in a way that each colonial countries was trying to have political, cultural and economic influence in Iran by using method in accordance with its wishes. So it can be argued that most of the political, social and cultural developments of contemporary Iran have been a function of the behavior of the colonizers and competition among them. The emergence of intellectual currents and even 
political parties clearly supported at least one of colonial powers in Iran and were dependent to them. In the realm of thought, most intellectual currents in Iran were trying to accept Western culture and civilization and even supported its sovereignty in their homeland and in this way, a movement called " Europe tendency movement" was formed.

Facing of East and especially Iranians with modern civilization of West which began from fifteenth and sixteenth centuries made scholars of mentioned communities to show different reactions to it. Some of them became lovesick to its positive aspects in a way that they ignored the ugliness of aggressive and colonialist look of West. Some others chose to reject Culture and civilization of Wes due to ear of political domination of European and Western beliefs over people. In the meantime, there as a third groups who their to face West civilization realistically and critically by observing growing weakness of their country as well as significant progress in the field of Science and Technology of West and tried to adopt positive aspects and reject negative and colonial aspects. Scholars in this group tried to take sufficient advantage from positive aspects of West civilization while preserving their national and religious identity and make negative aspects and the "ugliness" clear for the people of their negative aspects and the "ugliness". Seyyed Ahmad Kasravi was among these thinkers and scholars.

Kasravi was among the first individuals who have investigate in Iran about West's cultural invasion against Iran in detail and scrupulously and have examined various aspects of it. He has warned everyone at the time when not a lot of people paid attention to West's cultural invasion and has analyzed the Western life and has tried to find the roots of its main problems with close attention and has attempted to present solution. He warned Iranians about good and bad of Culture and civilization of the West at the same time and expressed about what Iranians must learn and adapted from the West and what they should not accept and refrain from accepting.

Given that Kasravi is a special and unique face in the history of contemporary Iran and his thoughts faced with very sharp reactions and was eventually killed due to his ideas, evaluation of his thoughts about the culture and civilization of the West is very important, especially since is mostly believed to be a secular thinker, so the first judgment is about his tendency to West and embracing the culture and civilization of West in a way that the write himself has had such impression studying his works and articles. But the fact of the matter is that Kasravi has rejected many of the negative aspects of the culture and civilization of West with sobriety and realism while studying various aspects of West civilization and has emphasized the masses of people, especially the elite to refrain from accepting them and at the same time has defended the positive aspects of West civilization, especially in the field of science and hardware technology.

To evaluated this matter, the present study tires to answer this question that what are positive and negative aspects of the Culture and civilization of the West from Kasravi's perspective? What aspects of the Culture and civilization of the Wes are adaptable and acceptable from his perspective and what aspects of it should be avoided? Can he be considered as critical of the culture and civilization of the West? In addition to a brief review of his life and expressing how he met the Culture and civilization of the West and also his theoretical concepts and fundapsyches. His writings have been discussed without the mediation to answer these questions.

\section{A GLANCE AT LIFE OF KASRAVI AND HIS FAMILIARITY WITH THE CULTURE AND CIVILIZATION OF THE WEST}

Seyyed Ahmad Hokmabadi who later adopted the surname of Kasravi was born in 1269 in a spiritual family in Tabriz. After studying seminary for being spiritual for a while, he gave it up and joined the Constitutional Movement at its beginning in Tabriz and did so much in the way of its victory. With the outbreak of the revolt of Khiyabani, he followed him but left it after a while. He went to Tehran in 1298

Submit Date: 01.05.2016, Acceptance Date: 23.06.2016, DOI NO: 10.7456/1060JSE/063

Copyright (C) The Turkish Online Journal of Design, Art and Communication 
$\mathrm{AH}$ and served in various positions in the Ministry of Justice, in Tehran and other provinces for twelve years. He left the Ministry after issuing a ruling in favor of Farmers of Varamin and to the detriment of the royal court and started legal profession. He started teaching in the Faculty of Tehran University for a short time. He published many works in the fields of on history, literature and linguistics during this time and along with administrative affairs.

From about 1929onwards, he spend most of his time studying in the field of social and political issues of Iran to remedy for them by understanding the secret of plight of political and social problems. The first results of his studies and his searches was a book called "Aiien" which it first part was published in 1932 and its second part was published in 1933. This book faced reactions in Iran and outside of Iran. Aiien indicates the theoretical foundations and principles of intellectual of Kasravi.

He founded "Peyman" monthly magazine in November of 1933 and published his thoughts in this monthly magazine as well as "Parcham" newspaper until the end of his life. In addition to these, he published dozens of books and he precisely criticized various cultural, social, educational, economic and political institutions and presented his solutions and suggestions to overcome existing difficulties and problems. He was reckless and daring to no one and nothing and lambasted everyone and that is why he created many oppositions and even bitter enemy for himself. Kasravi's social ideas which were raised in coherent and homogeneous and interconnected forms in various aspects gradually became an "ideology" or so-called comprehensive "way" which he named "puritanism".

Kasravi's supporters formed a party with him in the name of "freemen" and "puritans". This party became more formal in free environment after September of 1941 and occupation of Iran by the Allies - that led to the downfall of Shah - and continued its activities in the city of Tehran and other cities. Kasravi and the "freemen" party were under pressure from government and religious groups. Kasravi wrote some of his harshest criticism about clerics and the fundapsyches of Shia which led to reactions of different religious groups. Fedayeen Islam group led by Nawab Safavi was among religious groups facing Kasravi and his thoughts and Emami brothers who were among followers of Nawab Safavi eventually killed him and his secretary in April of 1945 during a trial by stabbing him with knife after several physical encounters with him and thus Ahmad Kasravi was killed but his thoughts and his writings are still a matter of discussion. As it can be observed in Kasravi's writing, existence of several consequences has been effective in formation of his intellectual personality as well as his familiarity with the culture and civilization of the West (Europe).

The first incident affecting the flow of intellectual training of Kasravi was formation of the Constitutional Movement. This is a fact that the basis and principles of Constitutional Movement are from west. He was about fifteen year old when he either met Constitutional Movement or became attached to it. "These were in 1285 and Constitutional Movement arose in Iran in the same year. The day movement started in Tabriz; people closed Bazars and have come to the British consulate and Samsam mosque, I heard the name of constitutional that day or the next day when I was coming from Colleague. It was the first time I was hearing it and I obviously did not know its meaning-I followed it too-I saw people there who were speaking to people and were saying the meaning of constitutional: "there should be rule using which people can live. King should not be arbitrary, a Parliament should be held that challenges things [consult]I liked these and became attached to Constitutional...". This attachment of Kasravi to the constitutional revolution remained with him until the end of his life and it never became weak and his efforts to solve social and political problems in Iran was continuation of the constitutional movement as he himself has said repeatedly in his writings. Kasravi became familiar with the nature of the constitutional revolution with the passage of time which was derived from ideas and thoughts of Western scholars and he wrote he most important book about constitutional called "constitutional revolution" which is still one of the most important resources in this regard and is the reference of Constitutional Movement's researchers.

Submit Date: 01.05.2016, Acceptance Date: 23.06.2016, DOI NO: 10.7456/1060JSE/063

Copyright (C) The Turkish Online Journal of Design, Art and Communication 
The second event in the life of Kasravi which led to his familiarity and at least the beginning of his familiarity with European culture and civilization and science was story of the discovery of Halley's Comet. Astronomers predicted the appearance of this star in 1290 which will occur every 75 years. This attracted his attention to advancement of knowledge in Europe. He himself writes about it: "this star and its story attracted me to knowledge of Europe and made me aware of it". This forced him to read books on astronomy, physics and mathematics. Kasravi realized this matter that familiarity with European languages is required to understand European knowledge and progress in their knowledge and he went to "Memorial" American School to achieve this which was launched by the American pastors in Tabriz. He taught Arabic and learned English there for about a year and a half. But the thing more important than learning English was becoming familiar with several Western figures at that school. This was s the first and the beginning of a direct relationship of Kasravi with the West and his familiarity with Western culture and civilization.

Third incident which was affective in his intellectual development and led to him being more familiar with European knowledge was finding a mistake in algebraic book from one of the American Scientists which was written in Arabic and was used in Lebanon and Egypt. Kasravi himself did not pay attention to this matter, but it seems that at the time when many Iranian intellectuals were lovesick to knowledge of West and unquestionably accepted whatever Westerners would say, a young Iranian objecting to an American scientist was very impressive at that time and it paved the way for him to critique European works and gave him required confidence to not accept Western imports unquestionably and without evaluation and not consider their products as unquestionable truth.

The fourth event which led to a transformation in his thinking and lead to his greater familiarity with the West was a trip he had to Caucasus region (Russia) in the summer of 1295 . He traveled to Tbilisi to find a job but he returned to Tabriz after 45 days in Tbilisi without finding a job. Even though his trip was short but it had long-lasting and influential results in his life. It's most important result was familiarity and friendship with liberals of Russia and the Caucasus region. He himself says in this regard: "the truth is that staying in Tbilisi for 45 days and efforts of Russian and Georgian and Muslim liberals transformed me". He also became familiar with Russian language in this short trip to a large extent.

In addition to above four matters which were highly influential in shaping his character and helped him become familiar with culture and civilization of the West. Studying journals and books of Iranians who traveled to Europe were very effective in this regard. He himself writes in this regard: "I took a series of books from him [who?] Which were very useful including Siyahatnameyeh of Ibrahim Beg Volume I and book of Ahmad and I read those. Siyahatnameyeh of Ibrahim Beg transformed me". In the meantime, Arabic and Turkish publications must be mentioned which were the main source of knowledge about western at that time and Kasravi read those too and has repeatedly mentioned those in the book of "Zendeganie man" and his other works. He refers to writings of Talebzade, Akhundzade, Mirza Malcolm Khan, Mirza Aqa Khan and others as well as "Akhtar", "Hagh Al Matin" and "Ghanun" newspapers.

However, origins of the intellectual development and the formation of character and thoughts of Kasravi were not limited to what was said. He became familiar with religious sciences based on routine of his time and memorized Quran in the beginning and went looking for its meanings beyond it. He says in this regard that: "This made me take time to understand the meaning of Quran (the meaning of the verses)... my first transformation in my thoughts and beliefs was in this way". Development of his thoughts and transformation in passing of time were the result of Intercourse between religious knowledge and western knowledge on one hand and adding his own thoughts on the other hand. 


\section{THEORETICAL FOUNDATIONS OF KASRAVI}

We should become familiar with worldview and theoretical foundations of Kasravi in order to understand his general attitude about culture and civilization of the West in terms of community and cultural issues. Kasravi has openly expressed his worldview and theoretical foundations in his books including "Aiien", "Din Va Jahan," "Dar Rahe Siasat", "Ma Che MIkhahim" and "Rahe Rastegari".

One of the worldview principles of Kasravi is in the field of nature (or the essence of human nature) which represents his difference with other organisms. He expresses in this regard in "Ma Che Migueem Va Che MiKhahim?" book that: "humans have two jewels in their nature: Life jewel and body jewel" (Life is a part of psyche). In his opinion "Life jewel and body jewel of humans are like animals and has all bad characteristics [mood, Ethics] of it from selfishness and anger and envy and hatred and cruelty and caprices and so on". But psyche is another thing that other organisms do not have. He says: "psyche nature is apart from others and it has tents of praising benevolence and compassion with others and justice and friendliness". Understanding and wisdom, thought and shame from family also come from psyche jewel. Kasravi also expresses about this matter in his book "Aiien": "humans have another jewel apart from body and soul which everyone has which is special to this kind and this jewel is called psyche. Humans have wisdom and matters which animals do not have". From his perspective "humans enjoy doing good things for others even at the expense of their own and also regret hurting someone".

Kasravi believes that religion, law, education and other social institutions have arisen from the "soul of man" and writes about development and advancement: "Humans are always in progress in their lives but this progress must take place in two ways: one trough creating means and understanding the forces of nature and so on which is from sciences and the other is though understanding the true meaning of the world and living and understanding the essence of every man and knowing its place among the creatures and living with wisdom and so on which must be called "the way of religion"'. He believes religion to be essential for the world and based on his various works, he believes the root of many of the major problems of Europe and the West to be exclusion of religion from society. However, he has his own definition of religion which is not the issue here. The important note is that Kasravi believes an entity named religion to be an inevitable necessity for world today.

Kasravi believes the most important factor in reducing tension and helping people to comfort to be "religion" in Part I of the book Aiien and in its fifth speech entitled "Europe removes the root of world peace" in addition to believing that the reason for plight of the world is tension and fighting among men and the fact that "everybody knows their profits at the expense of others". He believes "that religion does in this context cannot be done by anything else and enemies of religion can say whatever they want, we have tested irreligiousness which is the source of problems of the world and the enemy of world peace". Thus, Religion is imperative for the world even though indecency has been made in the past in the name of religion. He writes by emphasizing that "we have come from Asia" and Asia is the cradle of religion that religion is at first legislator which teaches a series of useful and precious instructions for religious people. It is a guardian in the second step which literally undertakes execution of those commands in overt and covert. It is a trainer in the third step which considers bad things not only as a sin but also as disgrace and considers good things not only reward but also as the source of good name not long after the time people know good from bad and honor can be found there among that group which is the most powerful agent of goodness in the world after religion. It is judge in the fourth step which believers who do good deeds for God and believe misdeeds will make His wrath, disgust bad deeds and find defamation in them and become close to righteous men and honor them".

Kasravi while emphasizing that the mentioned works are born of religion rejoices that such works are still expressing and speaks of several Iranian towns and villages which are not bound by European thinking

Submit Date: 01.05.2016, Acceptance Date: 23.06.2016, DOI NO: 10.7456/1060JSE/063 Copyright (C) The Turkish Online Journal of Design, Art and Communication 
yet to prove his point where characteristics such as: hospitality, integrity, charity, public security and ... are common. But these characteristics either do not exist or are very low in Iran's major cities where European thinking is common. He writes about this claim that law can compensate irreligiousness that: "The law alone can do nothing" just as in Europe with "existence of a lot of laws... lewdness is increasing". He mentions these words of president of America which were expressed among journalists that "we have tested that we cannot stop theft by law, we must bring honor to people" as the reason for this matter but he believed that "honor" cannot be found except with the help of religion. It is true that he believed in usefulness of law but believed that law alone cannot do anything because religion is different than the law and among its differences is that "pious desire to flee from sin" in religion but in law "Followers of law avoid crime only due to fear", "religion governs every matter of religious people" but law "only governs the physical body". Religion governs in both "obvious" and "secret" but law only governs in "obvious" and in the end, if we consider the benefit of law as one, religion has the benefit of ten.

Anti-materialism is among other intellectual foundations of Kasravi and the fact that world cannot be measured only by material progress and prosperity. He believes that: "Materialist philosophers have erred. World is not only the material and life is not a battle". In addition to pointing out that in a free market capitalist system of the West life has become more of a battle for avarice, he has condemned such attitude and believes that this battle should be the battle of ignorance and irrationality. He continues: "Anyone in this world is not free to do any wickedness and oppression... People should help each other and prosperous the world and take advantage of its good and fight against its bad. They must be able to help disabled people... they must fight the oppressors... anyone should consider goodness as a duty and should do good as much as possible". He believed that if men are supposed to compete with each other like other animals then "What is the difference between humans and predators?" today with this type of living of Europeans and other countries "what is the difference between men and wolves and leopards?" other than the fact that those Rip with their claws and teeth and these for killing and ... other losers have invented scientific means" and he believes that it is wrong to accept that life is a battle and anyone can use force and its ability "so why do you think thieves and bandits are doing the wrong thing?" because they are busy fighting too. This slippage from them is due to the fact that they have not understood the essence of man.

Kasravi believes by referring to the progress of science in Europe that this progress was along with spread of materialism and its bad trainings and led to plight of Europe because they were away from "code of life" The plight of Europe ... is related to the "code of life" and not to science. If we consider life as a home, "code of life" is its Foundation and "laws" are its wall and "ethics" is its roof. The major part of his publications including Peyman, Parcham and his other writings reject European materialism which is among his intellectual foundation and only a small part of it was referred to here.

\section{FIGHTING AGAINST FASCINATION AND ATTACHMENT TO CULTURE AND CIVILIZATION OF WEST}

In the time of life of Kasravi and when many Iranians were fascinated by the culture and civilization of the West and respected orientalists too much and this special respect coupled with interest and fascination was followed by not only ordinary people but also by elites of society, Kasravi fought against this attachment to the West and started this fighting by criticizing the research slippages of scientists who studied about East. A fighting which led to his greater familiarity with culture and civilization of the West and made him expresses various aspects of that civilization carefully and meticulously in his various works. That is why Kasravi should be considered among fighters of cultural front against the invading and cultural invasion of the West. 
One of the most famous East and Iranian experts which his writing are still attracting attention in academic circles is "Edward Brown". Kasravi found hundred and forty-two mistakes in his English translation of "Ibn Esfandiar" most of which inverted the entry. He was aware of level of erudition and precious books of "Brown" according to himself and presented several of these mistakes in his speech as example and he collected his mistakes and sent those to Edward Brown in form of a version with the help of Mirza Mohammad Qazvini. He also finds Twenty two mistakes only in a sixteen-page chapter of "Enough good and useful" by "Le Strange" but emphasizes that "name and reputation and knowledge of English scientist is not reduced due to these criticism and mistakes". He asserts that his purpose to find the mistakes of East experts is to both prove the mistakes of the author with "proof" and "reduce the exaggeration and extremism about writings of European East experts".

In other place, he expressed about immeasurable optimism of people to Europeans and uncritical acceptance of any European statements about history of language of Iranians that: "I sought more than anyone in my book to break this clause, I wanted Iranian people to understand two things: one is that East experts are not at one level and if there are high level scientists among them, many of them are also low level" and "other is that paying attention to these entries are not Specific to Europeans and if some of the Eastern people pursue the same way and equally suffer, they will have better results". Pain and plight of Kasravi's times continue in greater measure these days and many Iranians prefer Western researches to their own researches especially in the field of humanities.

Kasravi goes beyond this and in addition to blaming Iranians due to accepting any Western writing, writes in this regard that: "most people in Iran who are dealing with printed matter and read books believe that Europe authors and scientists are superior compared to Asian authors in any field of science and technology". He admits West scientists have taken the lead in natural, industry and some other fields of science. He expresses in this regard that: “... there is no source and document about hieroglyphs and things like this in the history of ancient times other than dead-lines and ruins and we in the East do not have access to such things so we have to be students and midgets to Westerners. But is it acceptable that Europe authors are superior to Iranians in that section of history and geography of Iran which is obtained from Arabic and Persian books? And can we accept any book which is written by them without argument?" Kasravi believes complication of our history, language and literature by foreigners who are "hundreds of miles away from us" to be "wonder of time" and writes that many of them who are East experts "are using being Iran expert as a means of avarice and fraud and they have stolen many of writings and sayings of past scholars and spend it treacherously and perhaps they publish these meaningless words in the name of science". He stresses that if someone focuses on their writings and speeches "they should not accept those words" and he also adds "if a book is written in condemnation of them, it is justified". He has many examples of this.

\section{EUROPE TENDENCY MOVEMENT AND ITS ROOTS}

Kasravi then raises a subject entitled "Europe tendency movement in Iran" in fighting against fascination with the culture and civilization of the West and wholeheartedly fights this movement and its leaders and supporters and he expresses with this believe that Europe tendency movement eliminated many Iranian humanitarian and moral characteristics and did not replace any remarkable thing that: "For years, there has been a movement in East, a movement that has not been seen in history before. Eastern people are all trying to make their countries similar to Europe, make West laws govern them and make Europe ethics common among their families. Men and women adorned themselves in the way of Europeans and they are proud of themself. Sole ambition of every country is to reach to Europe as soon as possible and find the civilization and they are so berserk that they forget the most precious reserves of East which are religion and piety and morality". Kasravi points out that "this land [Asia] has been the cradle of prophets and religion around the world" and questions why they now consider "religion and piety" among the most humiliating things and put many honorable and humane characteristics such as "true-heartedness and

Submit Date: 01.05.2016, Acceptance Date: 23.06.2016, DOI NO: 10.7456/1060JSE/063 Copyright $($ C) The Turkish Online Journal of Design, Art and Communication 
generosity," "hospitable and ", "arrest to droop" away. He refers to Praised Iranian culture about encountering with woman and celebrating them and is concerned about Iranian blindly imitating West in dealing with women and blames such behavior. He expresses about this matter: "... how is it possible that some believed the presence of women in community of men to be a disgrace but now they take their wives and sisters to dance parties and ..." He refers to Iranians with experience of living in Europe especially young people who have returned from Europe and writes about them: "they believe whatever they saw in in Europe is a condition of civilization ... they have objection about lack of it in Iran ... they disgraced their country". He stresses that there is no Youth who has not humiliated his mother and sister due to the fact that they have not learned "Tango" or have not put themselves "next to strange men" and they mistreat them.

Kasravi who has witnessed many events and the presence of foreign military attaches in Iran after constitutional, Raises another issue that expresses Cultural Inferiority and intimidation of Iranians and the fact that we no longer can and expresses that "we have no man" and "we have no human" which results in entrusting affairs of country to foreigners. He stresses that "each of these sentences is speaker's ransom and these subhuman should be punished and these subhuman roots should be dug from the earth". Writings and speeches of Kasravi have been raised about infatuation and fascination of Iranians to culture and civilization of the West in different aspects and have been repeatedly mentioned in his numerous publications all of which cannot be reviewed in this short article and what was mentioned was merely as an example.

Ahmad Kasravi believes the history of this movement (Europe tendency Movement) from the time when "machines and large factories and warehouses became full of merchandise" in West and forced European governments to seek market in the East. "They sent Tourists one by one or in groups to cities of East with this purpose" to do marketing work for them and thus, when they had the fortunate, they created liberation or European movements in the East. Despite the fact that he defends the constitutional in different occasion, he believes constitutional movement in Iran to be the start of Europe tendency in Iran. However, he stresses that leaders of Constitutional Movement "did not want anything from constitutional other than constitutional and order and just wanted to take a few thing from European culture" but soon, justice would give its place to Europe tendency. After the end of Constitutional Revolution, many writers and speakers arising from people wanted nothing but Europe tendency. According to them "Europe is a mine of anything good and European men and women are angels on earth. The whole world does not have civilization and this gift is specific to Europeans ... Iranians should learn whatever there is in Europe including rules and ethics and habits". He writes by referring to words of people like Hassan Taghizadeh: "one has reveals his purpose and has boldly said: Iranians must become like Europeans by their body and soul" and youth believe the beginning time of their land to be the time when Europe tendency started and consider their former illustrious history as nothing.

From the perspective of Kasravi, individuals and groups who provoked European Movement in Iran were "shameless people and "ignoble supporters" and "ignorant untried and youth" and "mercenaries of European companies" who ignored all precious reserves of East because nobody stood against them and paved the way of Europe tendency for themselves and others. He explains that supporters of Europe tendency criticize all good and bad matters of people which their art which is "ridicule and reproach" because ridicule and rebuke are the most deadly weapon to subdue others. He expresses about this: "poor dupe Iranians suddenly found themselves in the middle of a fanfare. They opened their eyes and saw people who are hardly tying and are all together to criticize everything they have from religion and ethics and habits, speech, and behavior. Those who have listened have heard that: there is a land named Europe which is paradise on earth and its people are like angels". He stresses that if European governments had sent "Millions" of black people to Asia and had spent "millions" of dollars, they could not have

Submit Date: 01.05.2016, Acceptance Date: 23.06.2016, DOI NO: 10.7456/1060JSE/063 Copyright $($ C) The Turkish Online Journal of Design, Art and Communication 
revolutionized East and lead them Europe to so easily. It will be clear if we pay attention to this speech that Iranians became fascinated by the civilization of Europe regardless of their own without trying to realize its nature and identity even to some extent. In other words, they became intimidated very soon and were placed in a quite passive situation and intellectual elite and community leaders especially the clergy could not have a measured and correct reaction to arrival of Europe's cultural institutions.

Kasravi believes the result of Europe tendency of Iranians and people of East is losing their own reserves. He concludes by assessment of what we have received what and what we have lost that we have lost "religion and piety and generosity and compassion of the poor and contentment and other such commendable morality" or were reduced and instead we have introduced "son-religious and nonrighteousness and selfishness and hedonism and greed and indigence and militant and ..." in the society. He cites many examples to prove his point which indicates his reasoned and careful investigation about social and cultural situation of Iran in the heyday of "Europe tendency".

Another consequence of Europe tendency was disdain and despise of Eastern people by Western people. Kasravi stressed that "Europe despises the East" and talks about presence of Europeans in Iran and other Eastern nations and the fact that Europeans believe that "they are different from Eastern people". He refers to writings of the Europeans about the East and advises his readers to "read books which Europeans have written at that time about East" to find out how they think about the Eastern people and disadvantages they have mentioned about them. "They have blamed everything they have seen in East". He wants to prove this claim that Western people believe to be superior compared to eastern people by citing examples while the reality is otherwise that is why he asks eastern people and the Orientalists to refer back to the history of East to determine that east especially Middle East has been the cradle of human civilizations and eastern people are pioneer in humanity and morality.

\section{EXCUSES AND PRETEXTS OF EUROPE TENDENCY}

Kasravi has then addressed pretexts of Europe tendency or present terms Westernization in the East some of which such as "civilization" and "law" have an enviable track record in the East, especially Iran and development of some of the sciences and technologies are not compelling reasons to abandon reserves of the East and previous reserves can be kept in addition to enjoying the new science and technology and new science and technology can be used in order to consolidate and develop them. However, he asserts that new sciences should be directed towards prosperity and "pleasure" and "comfort" of people and "the world". It is also necessary to remember that his approach to such issues is emanating from the theoretical foundations of his regardless of slight difference between opinions of Kasravi and past and present critics in facing with West's cultural invasion.

Expressing the general topic of "civilization" is one of the pretexts of "Europe tendency" in stimulating and encouraging the Iranians to culture and civilization of the West. They claim that civilization is specific to Europe and the West and other nations, especially Iran are deprived of civilization. In fact, the main excuse of Europeans to start being in other countries which is the start of colonialism was that we are seeking development and civilization in other lands as "a white man's mission" because we are civilized and other countries are not and gradually some people of colonized territories also believed Europeans are true and they must surrender against them and be subservient so that they can have civilization too which means they believed that they do not have anything and everything is in Europe and if they want to reach Europeans, they should become similar to them because they have "civilization".

Kasravi who witnessed the presence of Europeans in Iran and had a complete understanding of modern culture and civilization of Europe with very deep and extensive research in the field of culture and society of Iran and Europe and on the other hand was fully aware of intellectual richness of Iranian culture and even the East and their civilization history, talks about the meaning of civilization and method of its

Submit Date: 01.05.2016, Acceptance Date: 23.06.2016, DOI NO: 10.7456/1060JSE/063 Copyright (C) The Turkish Online Journal of Design, Art and Communication 
emergence and concludes that civilization is nothing new and many of the nations of the East especially the Iranians had civilization Since ancient times. However, he offers his own definition of civilization which was different from West civilization "... the literal meaning of civilization is "urbanism" and its foundation is complication of people in life and living equally with each other where capable cannot overcome disabilities" and "first and correct definition of civilization is that those who are reach will not have superiority over those who are poor" and this is what is praised by wise and elders. He considers the European definition of civilization which is "reading, writing, science and art" among the people and also emphasizes that "we also believe writing and reading to be obligatory for every man and woman" but his definition of civilization is not "guarantor of peace and happiness of the people". Because people with knowledge and art may turn on humanity and reach overcome the poor and deprive them of the joy of life. So Kasravi concludes that "it is not correct to consider Literacy and knowledge as civilization" and this matter has not been the objective of great and wise people.

In addition to this, Kasravi also provides another definition for civilization which intended by Europeans: "living with vehicles and airplane and cinema theater and novels and newspapers and ungodliness and fearlessness and in one word "today's Westernization" with all of its good and bad and people's lives without these matters would be considered without civilization by West policy makers and believe encroach on their country with the pretext of "learning civilization". He stressed that inventions and industries in Europe are "tools of life" and not "civilization" and enters this objection that "Why do we call it civilization?" and " Why we do not say industry and invention?" and responds to this question in this way that "do Europeans consider industries they take from each other as civilization?" Kasravi writes at the end of this article: "civilization which is called "popular" in our civilization ... is greater in Iran and East countries". He adds that prophets who laid the foundation of the goodness of "civilization" chose Asia as their homeland and the guardian of these will be nothing but Asia. Thus, the prophets have risen from Asia and have brought religions each of which has been source of comfort and delight of the world for centuries. "Were the lands of Zoroaster and Jesus and Muhammad bereft of civilization? Of course were not". In this case, he believes based on this definition that not only Europe due not have civilization, but he also believes that Europe "has lost its mind due to inventions" because "mass groups of people are will not have comfort" after industry progress and innovation and the rich and powerful do not pay any attention to them and are seeking their own dreams of capitalism. From the perspective of Kasravi, civilization is not living in cities while "desert tendency" is also not living in the desert. Dessert is where a group of men have oppressed of another group".

From the perspective of Kasravi, another pretext of Europe tendency is the progress of science in Europe. He has divided "useful" and "useless" sciences with full awareness of progress of science in Europe and raises this question that: can every science be useful and good? Can we be proud of those sciences from which bombs and tanks and human killing gases have been created? ..." he mentions the share of different nations from the old days to today in the formation of human knowledge and notes that a part of science that Europeans have today is the result of the efforts of ancient people. But the important thing from the perspective of Kasravi is that "Sciences have had more advantages than disadvantages before falling into the hands of Europeans and had no disadvantages" but nowadays, disadvantages of Sciences are more than their advantages. He admits that sciences such as "medicine, astronomy, history and so on have had much progress in Europe but sciences which come from infernal tools have had several times larger development, and ubiquity.

The main thing for Kasravi is that "The world needs satisfaction" and this satisfaction is not possible except with "religion" while one of the main results of the progress of science in Europe has been "spread of irreligionist". "Religion and piety are humans' makeup" and the one who does not have such makeup is like a thief who moves with a light and inevitably will hurt several times greater. "Bad human Sciences in

Submit Date: 01.05.2016, Acceptance Date: 23.06.2016, DOI NO: 10.7456/1060JSE/063 Copyright (C) The Turkish Online Journal of Design, Art and Communication 
Europe" should have made today's Europe a heaven on earth. Yet today, the condition of Europe is the best evidence that those Sciences are nothing but disgrace for mankind". He expresses this disadvantage about European and believes this to be a great shame that "sciences have raised from filth and temper tantrums instead of righteousness". "It is only enough to sat that deviation of knowledge of Europe results in irreligiousness". The only which has been spread from all of those "Academies" and "knowledge societies" is irreligiousness.

Kasravi believes that Europe is only a "blacksmith" from the perspective of profit and loss of the world despite having all of these arts and knowledge and inventions and discoveries because the result of all of those inventions and discoveries is only changing "means" of life. He judges these sciences with work of prophets and writes: "...Prophets were the world's healers" and tried to provide "comfort for the world": but nowadays, Europeans are presumptuous to their knowledge and criticize teachings of prophets and have put them aside. He mentions in message to scientists in Europe and America as well as fans of "Europe tendency Movement" that World Wars I and II have been the result of new knowledge in the West. "This is the result of the fact that large states have established many factories in their home countries and need distant lands to prepare the market to sell and obtain raw materials".

The third pretext that westernizers and as said by Kasravi "Europe tendency" want Iran to compliance west is the issue of "Law". He defends the system of rules in formed in the West and believes its origin to be "philosophers of ancient gods" which has grown especially in the field of Islam and Muslims lived with this "ritual" for centuries but Europeans have promoted "freedom and equality" in their homeland in recent centuries in due to efforts and "devotion" and it has come back to East from there. But he believes that these "rituals" and rules are different from basic principles. "What type of equality is this when a group is in full wealth and a multitude of people are bereft of all joys" or "What type of equality is this when one is reach and the other is poor".

Kasravi has honored receiving praised laws from the west which also have roots in east such as equality" and "fraternity" by dividing Western laws into "commendable laws" and "very injudicious laws". But he believes that this is wrong to "praise all of Europe's Laws" and adopt and promote all of them "what we should say about a group of people in east which is the land of regulatory and borrow laws from the farthest lands?" he believes that law is an important factor in human life and can be "useful" and "harmful" at the same time and its "harmful" form should be avoided. There would be no problem if we had no law or the European law was better but the reality is that "eastern people" have had deliberate and tested laws and this is miserable and helpless to use "injudicious laws" instead of them.

Kasravi mentions an example in this regard and notes that: "Iran has had king from thousands of years before and took taxes from farms and has had laws for these which have been inevitable result of intelligence and test of several thousands of Exchequers and Secretaries and were able to do tasks with simplicity and ease until these were dealt with the name of Europe tendency from the Constitutional and people would come from Europe and found current law and modern office with exorbitant monthly Salaries. Supporters of Europe say what was the disadvantage of the ancient law? And what is the advantage of this law?" he wants Supporters of Europe to evaluate between "Two Iranian and European laws" in order to reveal their "deviant" and "helplessness". Laws of Europe are "complicated" and have many useless clauses which lead to bewilderment. Law must be in the right way and "Joinery" and "discerning" in the field of law is a flaw.

He believes one of the excuses and pretexts of Europeans to offer patronage to other lands is lawlessness and writes: "Europeans talk about disability and Resourcefulness of east and Mandate some lands for this pretext and use many countries. Their sole reason is that there is no law in the east and tasks everything is disorganized". He claims the superiority of Europe to be absurd in this case and does not believe the

Submit Date: 01.05.2016, Acceptance Date: 23.06.2016, DOI NO: 10.7456/1060JSE/063 Copyright (C) The Turkish Online Journal of Design, Art and Communication 
existence of invented instruments which are used for "conflict" and "hurting people" the reason for superiority and that is why he considers "lack of law in the East" baseless and absurd. He believes the only disadvantage of Eastern people compared to Europe is meanness and corruption because they discard their "goods" and obtain their "evils" and they "give gold and take copper".

Kasravi compares laws of Islam and Europe in proving his claim about useful laws in East and writes: "... judgment has been one of the most precious things of Muslims and caliph chose judge for any city. These judges were skillful in his duties and everyone should obey them". He refers to the fact that "jurisprudence" among Muslims is same as law in Europe and has pointed to special place of Jurisprudence and jurists and the fact that "they accumulated knowledge" and "helped in prevalence of science and religion" and believes that "The law of Europe" cannot be matched with it and best "judicial procedures" in the world have been flowing in Iran and Islamic countries for centuries which is much better than "European law". Only one judge was enough for each city in those days with hordes of people in towns and villages and "increased immensely and prevalence of transactions and commerce. But the Islamic Penal Code was gradually lost with the fall of the Caliphate and Mongol domination and that is why the subject of European law took shape following Ottomans and French law was chosen and "Foundation of Justice" took shape. He asks this question by counting French Foundation of Justice which was used in Iran that "Isn't the law of Islam better and closer?" he adds that it would be better if we had access to what Islam says. In addition to this, he writes: "if jurisprudence was the source of judge and legal actions, this country would have the best Justice and perhaps Europeans would follow it someday". From the perspective of Kasravi Europe judicial Act is "the most injudicious law" which has no result for people except for suffering.

\section{OBJECTIONS AGAINST WEST CIVILIZATION (THE NEGATIVE ASPECTS OF WEST CIVILIZATION)}

Entry of Culture and institutions of the West to the land of Iran and other eastern nations led to mixed reactions. Groups which were opposed to acceptance of this so-called "new civilization" and only agreed to take parts of it, such as "Industry" and "inventions" were extremely rare compared to other groups. Kasravi tried to prevent his countrymen to fully accept it by introducing negative aspects of this civilization as one of the most prominent members of this movement with full knowledge of the culture and civilization of the West which he had obtained from different ways. However, he claims that he is not looking to "find defects" of Europeans and is trying to clarify "their bad condition". However, the readers which take the massage of negative aspects and drawbacks of culture and civilization in the West from his books. It should be noted that his view of culture and civilization of the West and expression of its problems are caused by his special theoretical foundations and world view but the problems that he mentioned have now been accepted by many scholars and even among the Westerners and they are trying to solve those.

Kasravi starts the second speech of the first section of "Aiien" which this question: "is the world moving forward?" and writes: "Europe talks about making global progress in the shadow of inventions which have made the world a better place from two or three centuries ago" and then asks: "we must see what the world is looking for" and answers this question in this way that we and Europe are moving toward a single destination which is "comfort and pleasure". But he asks: "have the modern inventions of Europe added to comfort and happiness of the people?" and answers this question with "no" and not only these have not led to satisfaction of human, the contrary "the result of these innovations and changes which have inevitably occurred in the life have increased the effortlessly of people".

He raises many questions in another speech of "Aiien" entitled "the result of innovations in Europe" including: "doe people have one day of work and one day of comfort and joy after various inventions

Submit Date: 01.05.2016, Acceptance Date: 23.06.2016, DOI NO: 10.7456/1060JSE/063

Copyright $($ T The Turkish Online Journal of Design, Art and Communication 
unlike other times?", “do people sleep and eat more?", "do they live longer?", "is poetry gone?", “is enmity among the people gone". His answer to these questions is negative and concludes that "a tree can be recognized by its fruit, what are the benefits of these inventions for human beings".

Kasravi is trying to find "bad situations" of Europeans in the seventh speech of "Aiien" entitled "The plights of Europe" which we call objections against culture and civilization of west. He has also talked about this matter in "Peyman" magazine as well as some issues of "Shafaghe sorkh" and the book of "message to scientists in Europe and America" so that he can be "a source Awakening" of eastern people according to his book and perhaps Europe can also benefits from compassionate criticizing and cure itself. According to Kasravi, "prevalence of irreligion" is one of the most original and most important negative aspects of West civilization. He states Religion to be "highway of life" in second speech of book "Rahe rastegari" entitled "What is Religion and what is Religion made for?" humans should have a way in their lives and that way is Religion. People need religion due to two reasons: first because they have reason and wisdom and "must know the world" and the other because they live in one place with their fellows and are socialized and "there must be a sophisticated ritual" so that they can live in comfort and peace. He wholeheartedly defends the rule of religion with all of its deformations among people of various territories-especially east- by enumerating the various aspects of religion and its function in human life from ancient times to the beginning of inventions and discoveries in West by accepting deviations in the various Christianity, Islam and ... religions most of which are due to incorrect perceptions and behaviors of some religious leaders. Then talks about the reasons for decline of religion in Europe which gradually led to the "irreligiousness" and he believes this "irreligiousness" to be the result of irrationality of Western philosophers and scientists and extremely hideous behavior of Church in the Middle Ages.

He clearly expresses in this regard that: "were are those European philosophers who mocked everything risen from God and religion a hundred years or two hundred years ago stimulated humans to follow livestock to be here now and watch the fruit of their planted seedlings" and then adds: "we have injudiciously led our young people to spread poisonous thoughts of others among easterns and we will not stop mentioning its disadvantages" because we know the result of poisonous thoughts and know that their prevalence among the people will cause "inadmissibility". Kasravi has considered the "plots of Priest" as another factor of "irreligiousness" of Europe and says: "... people were tired of plots of Priest because Priest were working with kings and tyrants to punish rebel and people started to consider the Religion as enemy because they did not know any other Religion". However, in addition to the factors mentioned, Kasravi believes the most important factor of "godlessness" in Europe is the regress of science and inventions and feeling no need after Invention of Machine.

Kasravi stressed that "Religion is Foundation of an array of precious and good deeds and commendable Morality" and adds that honesty and sportsmanship and avoiding wrongdoing and hospitality and "other good deeds" have fallen wherever that "religion has fallen from glory" and "stealing and lying and deception and the love of money" and other ugliness have spread instead of those. He believes that "Comfort and pleasure" of the world can only be achieved by "maintaining religion". He writes in answer to those who say "law" takes the place of religion and fills the gap of and irreligiousness fills the gap "law in the absence of religion "has no benefits and tests of Europe itself have proven this claim.

Machine is among other $r$ negative aspects and according to Kasravi "plights" of west. He has spoken about Machine and its consequences on people's lives in detail in his various works. He divides the European inventions into two groups: one is those which work for all people such as automobile, the telephone, and the electric light and ... and the other is those which work only for wealthy people and he believes this last group to be the cause of destruction of the world. "Today's situation of Europe with is the most apprehensive situation is only the result of those inventions". In his opinion, except for "some

Submit Date: 01.05.2016, Acceptance Date: 23.06.2016, DOI NO: 10.7456/1060JSE/063 Copyright (C) The Turkish Online Journal of Design, Art and Communication 
medical shoes ... none of the European inventions are good and appropriate. He writes by referring to history of the invention of Machine and formation of various factories in the past three centuries that at first "everyone thought that these tools will be a source of comfort for workers" and were hoping for better and prosperous world but after a short time, it was determined that these tools are "infernal" and they are become "enemies of peace of the world".

Kasravi is aware of this claim of Europeans which says "machines can reduce human suffering and machine can weave a hundred pairs of socks in one day instead of weaving two pairs of socks in one day and does not deny the profit of machine, but he believes that "it causes too much damage". In short: "if machine has reduced the work from machine one hundred to one, it has increased sufferings from one to one hundred" and then talks about damages of machine. These damages have had bitter consequences for the international community from Europe to other lands.

Formation of factories and Invention of Machine led to inability and helplessness of countless workers and "other than the fact that thousands of workers work in each factory for small payday" Kasravi refers to the launch parties and trade unions in the West and considers it as a result of this injustice which is considered as a great shame for Europeans. He writes: "this is a great shame for Europeans ... which has led to formation of parties and trade unions which are enemies of wealthy people and are always looking for opportunities to eliminate them". He refers to political parties in East and especially Iran and writes: "supports of Europe have given another meaning to these political parties in east and Praise it as one of the techniques of Governance" while it is only a lie to cover defects of Europe.

Imposing manufactured goods and incitement to consumption are among other damages of Invention of Machine especially those goods which their existences are not necessary in people's lives "most of what these factories make, weave or produce are nonsense and rare [unnecessary]" and manufacturers "force people to buy those" and take the assets of people with deception and falsehood.

Another disadvantage of machines and factories from the perspective of Kasravi is battle to gain market sales. First and Second World Wars were the consequences of the industrial revolution "Merchandise too much has been made to much for public and inevitably contraction is created in the market... factories of each country wants to have universe for themselves and do not let other foreign factories there". Thereby rivalry, enmity and competition take shape and lead to war and bloodshed in the world. The worst is that it has made transactions to be the principle and living to be its corollary", while transactions are for life and we must purchase what is necessary for life and do not buy what is not necessary but "Europe is opposed to this idea and considers trade and traders as the original purpose and considers life as a way to reaching this purpose" that is why various European forums are seeking to sell their manufactured goods. He speaks in detail in several occasions to substantiate his claim "for example, if a tool is built for war and is not sold due to lack of war, a war is created in a place to achieve this purpose". Current situation of the world and existence of wars and strife among nations, especially in the East are proof of his claim.

Kasravi then refers to "capitalists in Europe" in discussion of transactions which should be a source of comfort for people and says that they have created "bad precedent" in this way that "they force people to buy whatever machines make". He believes this bustle of those days-men and women seeking to buy clothes and footwear, makeup nested of moral virtues and ... - are caused by this "bad precedent" which is machine like transactions.

Unemployment is another one of objections and negative aspects of Western civilization which in itself is created by machine life. In addition to this, from the perspective of Kasravi, "freedom of work" has increased unemployment because it goes back to machine and factory "unemployment of workers is due to increasing machines". He refers to West economic crisis particularly in the interval between World War I and II and famine and hunger in most European countries and believes this situation to be the result

Submit Date: 01.05.2016, Acceptance Date: 23.06.2016, DOI NO: 10.7456/1060JSE/063 Copyright (C) The Turkish Online Journal of Design, Art and Communication 
of machines and factories and disassembling the freedom of work and writes: "Hunger is not due to drought and is due to advent of machines and factories and disassembling the freedom of work which have prevented Craft workers and artisans to work".

He refers to the fact that officials of Europe claim that "unemployment crisis" is due to special circumstances and that it will pass and writes: "crisis is only a Concept, world has never been free of war, movements, and these events, so the crisis must have always existed. The emergence of machines has led to this situation. The place where a machine carried out the job of one hundred workers, it is obvious that ninety nine workers will be unemployed". Economic crisis of West and other parts of the world in recent years which unemployment forms a large part of it reflects the words of Kasravi.

Kasravi writes in a speech entitled "Madness": "this disadvantage for machine is enough that it has made the world confused and mad". "There is no madness greater than the fact that trading has lost its meaning and it has become a problem for the world". He refers to a delicate and subtle matter by referring to abundance of industrial goods in the market based on which: "...factories should make or weave everything a poor quality so that there will always be buyers and machines will never stop working". He believes such work to be "insidious" and "injudicious" and is surprised that eastern people use and publish it and believes that these are not aware of its losses.

Kasravi refers to statements of Machiavell in the field of i policy which has named it "Black empathic statements" and fears that such dire situation will spread to other fields: "if this dire guidance of you reaches other works from factories and doctors used it to increase patients and architects build buildings in a way that they collapse or come crashing down after little while and increase prevalence of their works in this way, how will the world look?" the in short term, he believes that "a good heart is required for the world more than anything" and Europeans do not have it and do not want to have it and the end on such process will be nothing but destruction.

Another one of criticisms of Kasravi to culture and civilization of the West is Unfavorable situation of women and he expresses his dissatisfaction in this regard. He is also dissatisfied with situation of women in East but in general, he evaluates the situation of women in east especially Iran to be better and more favorable than west: "If we treat women badly Europeans treat them worse". "Frankly speaking, European habits toward women are wrong and reprehensible like many other habits". He criticizes treatment of European with women and is dissatisfied that Iranian people follow European people. "The fact that European use women in professions related to men is wrong. If they like their mistake and are unwisely proud of it is not a good reason for others to like that mistake and follow it". "Are women is Europe that we want to follow them in Asia?" He criticizes the fact that Europeans create so much suffering for women: "isn't it in Europe where most women have fallen into wrong matters? ... Millions upon millions of Auxerre girls work in factories and mines and nobody cares for them" and the wonder is why such behavior with women should be emulated by others. He was upset with Iranians because they were blindly following such behavior. Kasravi expressed that "Westerns consider women as lust puppet" so "they held dances and parties and drinking for them before anything" and named it freedom of women and compassion for women while all of these are for good of men. He expresses with referring to Iranian women following the Europeans that: "Iranian women learn two bad things from Europe: one being adorned in the presence of men and wearing their best fashionable clothes in streets" and the other is "interacting freely with men and arbitrary going to parties". He emphasizes that both of these are wrong and invites Iranian women not to fall for such words and deeds.

"Iranian women must know that woman is not esteemed in Europe... they should not fall for words in the newspaper" and adds that such behavior with woman is delusional. Europeans are delusional in many

Submit Date: 01.05.2016, Acceptance Date: 23.06.2016, DOI NO: 10.7456/1060JSE/063 Copyright (C) The Turkish Online Journal of Design, Art and Communication 
aspects and one of them is women and they believe women to be a tool for leisure of men and nothing more. Kasravi believes such behavior of Europeans toward women to be delusional and has asked Iranian women and girls to stop following such misguidance.

\section{CONCLUSION}

Kasravi has many writings about culture and civilization of the West. What was mentioned in this article was a summary of his views and opinions which were expressed in compressed form. In general, he tried to see both good and evil of west and evaluate and discuss those in his "balance measurement". He has portrayed the negative aspects of West civilization in many of his writings, especially in his "Aiien". He is among those who have paid attention to this matter finely, detailed, reasonable, clearly and eloquently and has not been satisfied with generality. In other words, Kasravi has written about negative aspects and drawbacks of culture and civilization of the Wes better than anyone which many have remained hidden if he has not spoken about.

The reason that Kasravi has talked more about negative aspects of culture and civilization of the West is due to socio-cultural and political situation of his day when there was a kind of " Europe tendency Movement" and led them to the West. Europe tendency was denying and rejecting everything in Iran and admired belonged to the West and Europe and encouraged the people to follow it. Kasravi says: "I hope they talked a little about the flaws of west instead of praise and exaggeration of the West". However, he is not unaware of positive aspects of the culture of the West along its defects and has expressed those fairly and has encouraged Iranians and other nation to use those. He believes: "learn science and inventions of Europe" and "we need techniques and industries of Europe" but in general, he has paid more attention to negative aspects of West civilization for awakening of the world and alert them from dangers that threatens them and points out: "We are not hostile to the West... these criticizes are not due to hostility and are for alerting the world".

Kasravi states that Iranians have learned five fields from Europeans and have spread those among themselves and has judged about those which in itself indicate his general view about culture and civilization of west:

1. Constitutional government, living based on law, attachment to the homeland [nationalism] ... recruitment practices and...

2. New sciences such as geography, history, physics, chemistry, astronomy and...

3. Enabling knitting and weaving, agriculture, software and take advantage of Inventions machines,

4. Europe tendency and boasting about civilization and progress and party building

5. Materialist philosophy, bad training of materialism, knowing life as battle and steep and futile thought

He says three fields are useful and defensible and expresses the necessity of obtaining them but insists that these have defect too but they are defensible in whole and learning them is not wrong for Iranians. He writes about fourth and fifth fields that "The last two fields are bad and lead to losses" and he discourages Iranians to follow and implement them.

In short terms, despite the fact that Kasravi is strong critic of Iran's clerical class especially the clergy and has raised strong criticizes toward them and was finally killed by a part of the same religious movement (Devotees of Islam), but his views and opinions of the culture and civilization of West is largely close to views and opinions of the religious class and this is among the wonders of contemporary history of Iran. Nowadays, many much of the sayings and writings of Kasravi about culture and civilization of west are raised through different media and platforms and from clerical class. It should be reminded that Theoretical the theory and principles of thought of Kasravi are different compared to clerical foundations and principles but in any case, almost identical views about the West and its culture will come from these two streams and this indicates the fact that culture and civilization of the West is incompatible in most cases with culture and civilization of Iranians despite the positive aspects and every nation especially

Submit Date: 01.05.2016, Acceptance Date: 23.06.2016, DOI NO: 10.7456/1060JSE/063

Copyright (C) The Turkish Online Journal of Design, Art and Communication 
Iranians must continue to adhere to its rich culture and civilization in addition to application and obtaining new skills and knowledge.

\section{REFERENCES}

Kasravi, Ahmad, My life, first edition, Tehran, no less, in 1944

Kasravi, Ahmad, ritual. The first issue, Tehran, no less, in 1933

Kasravi, Ahmad. Varjavand Foundation, Tehran, printing Treaty, 1943, p. 28

Reservation, B.. Political trials in Iran (1954-1973), First Edition, Tehran, publishing and Science, 2003, $154 \mathrm{p}$.

Kasravi, Ahmad. What should we do today? Tehran, no less, in 1941, Page 25

Kasravi, Ahmad. My Life, p. 26

Kasravi, Ahmad. What we say and what we want? Second Edition, Tehran, and monthly magazine with ensemble Azadegan, 1947, p. 93

Kasravi, Ahmad. Regulations, Part I, Tehran, no less, in 1932, Ss7-3 / salvation, Page 20

Kasravi, Ahmad. Scientist's message to Europe, America, First Edition, Tehran: Bi-Na, 1942, p. 11

Kasravi, Ahmad. Treaty. first year. First Edition. Tehran, Ferdows Press, 2001, pages 408-401 / salvation, Ss28-24

Kasravi, Karvnd, a collection of 78 essays and speeches Ahmad Kasravi. John Zka efforts. Tehran, corporation, Pocket Books, 1973, p. 237

Kasravi, Ahmad. Regulations (Part I), p. 21

Treaty 2, pp. 507-506 / Regulations, Pages 23-22

The treaty, Page 508 / rituals, pp. 24-23

Kasravi, a message to scientists in Europe and America, 7 / Faith, p. 30

Regulations, Part II, pp. 73-72 / Treaty, Page 389

Kasravi, Ahmad. Sisters and daughters, first edition, Tehran: printing Treaty, 1944, p. 15 